\title{
3.8 .15
}

P972

1914

NMAH

THE

PUBLIC UTILITY

$\mathrm{OF}$

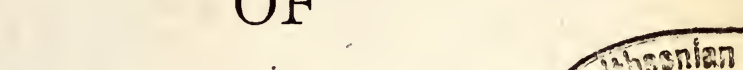

MUSEUMS 231330

Imperial Institute-Victoria and Albert MuseumKew GaRDENS.

OFFICIAL REPORT OF THE DEBATE IN THE HOUSE OF LORDS, May 20th, 1914,

In which the following Peers took part :

The LoRd SUdeley

The LoRd ZOUChe

OF · HARYNGWORTH

The LoRd ARchBishop of Canterbury

The Earl of Plymouth and

The Earl Beauchamp,

AND REPRINT OF LETTER FROM THE "TIMES." 






\section{8 .15}

\section{THE}

\section{PUBLIC UTILITY \\ $\mathrm{OF}$}

MUSEUMS

\section{0}

Imperial Institute-Victoria and Albert MuseumKew Gardens.

OFFICIAL REPORT OF THE DEBATE IN THE HOUSE OF LORDS, May 20th, 1914,

In which the following Peers took part :

The Lord Sudeley

The Lord Zouche

OF HaRYNGWORTH
The Lord Archisishop of Canterbury

The Earl of Plymouth and

The Earl Beauchamp,

AND REPRINT OF LETTER FROM THE “TIMES." 


\section{MEMORANDUM.}

The following are the Museums, Galleries and Gardens to which "Guide Lecturers" have been appointed, with dates:DATES.

1911-British Museum.

1912-Natural History Museum.

1913-Victoria and Albert Museum.

1913-Kew Gardens.

1914-National Gallery.

1914 - National Gallery of British Art (Tate).

1914-Wallace Collection, Hertford House.

1914-Royal Scottish Museum, Edinburgh.

Horniman's Museum (London County Council, it is understood, have decided to appoint a Guide).

Nothing yet done at-

The Bethnal Green Museum.

The Imperial Institute.

The London Nuseum.

The Tower of London.

Royal United Service Institution.

National Gallery in Dublin.

National Museum of Science and Art, Dublin. 


\section{"THE PUBLIC UTILITY OF MUSEUMS."}

\section{COPY OF OFFICIAL DEBATE, \\ Imperial Institute-Victoria and Albert Museum-Kew Gardens. \\ 20th May, 1914.}

Extract from Parliamentary Debates.

\section{Guide Lecturers.}

LORD SUDELEY rose to call attention to the Return on Museums lately issued, and to move for a similar Return for the current year, and also for a second Return deal. ing with the Provincial Museums; to ask whether any decision has yet been arrived at as to abolishing paydays at the Victoria and Albert Museum which, besides other disadvantages, are found seriously to limit the efficiency of the guide lecturer ; to ask whether it is proposed to appoint a guide lecturer for the Imperial Institute; and to ask whether further steps cannot be taken at Kew Gardens to make the establishment of guide lecturer more generally known.

The noble Lord said: My Lords, I desire to call your Lordships' attention to the Return lately issued on the subject of museums so far as it relates to the question of guides. As your Lordships are aware, there was a slight mistake made by which the number of visitors with the guides was omitted from the Return, but my noble friend Lord Beauchamp the other day explained the matter and showed that in the British Museum, in the Natural History
Museum, and in the Victoria and Albert Museum no fewer than 84,000 people had gone round with the guides during the time since they had been appointed. That proves clearly that the plan has been a success. In regard to the Provinces, it was shown last year that it would be difficult to have a Return for the 150 to 200 provincial museums because there was no Department which could authorise its preparation. The matter was thereupon postponed, and the Board of Education consented to enter into correspondence with those controlling the museums in the Provinces to see what was being done. Lord Beauchamp the other day stated that the Board of Education had done this during the recess, that the correspondence had been very voluminous, and that it was of a most satisfactory character showing that a great deal was being done by members of the staff and by other people who gave their services voluntarily to show off the exhibits in all these museums.

Since then, in April of this year, three large institutions have adopted the system of guides-the National Gallery, the Tate Gallery, and the Wallace Collection. The time that has elapsed is very short, but as far as I can ascertain from the different 
directors the system is working exceedingly well. Nothing but satisfaction has been expressed by all the visitors, and it is stated that the guides selected are particularly good and that the work is excellently done. I will not attempt to-night to go into the question of whether or not the appointment of guides is a good one. Last year your Lordships showed great sympathy with and approval of the movement, and it was generally demonstrated that it was a very good system. The results of the last year have proved clearly that to be so, and I will not weary your Lordships with any further comment. But although we have had great success in that now eight of the large institutions-seven in England and one in Scotlandhave adopted the system, there are naturally certain faults and blemishes. which ought to be put right. I hope that your Lordships will allow me to go through them shortly, and I trust that it may have the effect of getting the authorities to correct them.

The one great fault is that the institution which of all others ought to have been the very first to adopt a guide lecturer has not done so. That institution is the Imperial Institute, and it is a great pity that that should be so. The Imperial Institute is in the position now of being almost the last of the Government Museums and Galleries which has not adopted this system. I should like to say, in calling attention to that fact, that I appreciate most thoroughly the enormous strides that have been made during the last few years in the development of the Imperial Institute. Much good work has been done. There is one branch of the Imperial Institute which has done specially good work, and that is the research department. I am told that the result in regard to developing the resources and products of India and the Dominions has been most beneficial. I should also like to tender my humble praise to tiie director and staff of the museum for the admirable way in which they have arranged the products of the different countries and the careful manner in which they are all labelled. I am aware also that the authorities are strongly of opinion that it would be an immensely good thing to popularise the institution by enabling people who go there to be able at once to find out the characteristics and all the particulars of the different countries in which they are interested, by proper explanation. But the extraordinary thing is that, notwithstanding the fact that everybody seems in favour of doing this, nothing has yet been done and no initiative has been taken.

It is quite true that if a school or special visitors wish for information, some member of the staff of the Imperial Institute is detailed to give it; but that is a different thing from having a regular guide lecturer taking daily tours and always a vailable to give information. It is quite impossible for the staff in a museum or institution like that to be taken away from their various duties without considerable loss. It seems to me an extraordinary thing that the Colonial Office should have allowed this state of thing to continue so long. Is it not the case that the Imperial Institute was created with the object specially of being able to show the products and resources of India and the Dominions in the best possible way? It was 
also the great desire that it should be a place where people could go who were interested in India or the Dominions, either in regard to commerce or with a desire of knowing something of the capacities or possibilities of these countries for emigration, or for settlement, or for other purposes. Then am I not right in saying that when this Institute was created $£ 100,000$ was subscribed in India on the distinct understanding that their products and resources and their interesting examples of modern art should be thoroughly shown? This, unfortunately, has not been done. The general public are now keenly alive to the fact that all museums and galleries ought to be placed in such a position that their exhibits may be made a living reality to them. This is certainly not the case in regard to the gallery of the Imperial Institute.

Last March the Secretary of State for the Colonies, in reply to a question stated that the Department were unable to appoint a guide lecturer on account of the expense, and your Lordships will remember that last year Lord Emmott, in reply to a Question which I put to him, said the same thing. I am quite aware that the resources of the Imperial Institute are linited, and that it is impossible to do very much without some small grant from the Treasury. But what is required is merely $£ 200$ or thereabouts a year, and when you remember the great value of the exhibits and the enormous benefits attaching to showing them off properly, I am sure you will think that that amount is a very paltry sum. There is another reason. Already the Treasury have helped the various institutions, eight or nine of them, in regard to appointing a guide lecturer and have agreed to place in the Estimates a sum for this purpose. Therefore I cannot believe that if the Colonial Office really wished to do anything they could not persuade the Treasury to help them in the matter. Does it not look as if the matter is being trifled with? Does it not look as if they did not appreciate the enormous importance attaching to the development of this movement? I cannot conceive that India and the representatives of the countries interested, including the High Commissioners of the Dominions, will allow this matter to continue without putting it right. Surely it is a great injustice to the countries concerned. I trust that my noble friend will be able to give a satisfactory reply. I have heard from many people connected with the Colonies that they look upon it as quite a disgrace and a scandal, and it is certainly a more serious matter than the Colonial Office seem to think.

The next point in the Return to which I wish to call attention is the case of the Victoria and Albert Museum. I have put a Question down in regard to that-namely, to ask whether any decision has yet been arrived at as to abolishing paydays, which, besides other disadvantages, are found seriously to limit the efficiency of the guide lecturer. This question of pay-days at the Victoria and Albert Museum is a very large one. It has been going on for a considerable time. Originally when the the museum was small, pay-days, or students' days as they really are, were necessary. The space was limited, and it was necessary that full opportunities should be given to students. But long 
since that time the museum has attained considerable proportions. It has now a palatial building, and there is plenty of room, not only for the students in the galleries, but there are private rooms. In the year 1898 a Committee of the other House was appointed on the question of Museums. My noble friend Lord Crawford was, I believe, a member of it. I think I am right in saying that even at that time people were thoroughly satisfied that these paydays ought to be abolished. Their continuance is also most unfair to the director of the museum and the staff, who are most keenly alive to the harm that they do and most anxious to make the museum thoroughly efficient and popular.

The difference between theVictoria and Albert Museum and the British Museum as respects the number of people who are seen in the galleries is marvellous. I find that the amount received in the course of the year at the Victoria and Albert Museum from the fees charged on students' days is $£ 900$, which, taking each non-student as paying sixpence, represents 36,000 visitors, which, added to the number of students given in the returns, 23,558, gives a total of about 60,000 . When we reflect that a total number of visitors in the course of the year is 730,000 , it will be readily seen that the number of visitors during the three days in the week which are set aside as students' days is exceedingly small. The general result practically is that the Museum is closed for one half the year. I am sure the House of Commons would never have allowed that enormous sum to have been expended on the erection of the building if there had been any idea that for so large a portion of the year the museum would be practically empty. Your Lordships, I have no doubt, have constantly gone there. On those days, which are pay days you go through the galleries and see one, two, or three people only in some of them, and very often there are more attendants than visitors; whereas if you go to the British Museum, which is free, it is a crowded beehive and the difference is very marked. But in regard to the matter in which I am specially interested - the guide question-the result of these students' days is that on those days only about one half the usual number go round with the guide lecturer. That is a great pity. And with regard to that point I should like to mention this. It seems to a great many people that, until these students' days are abolished, it ought to be permitted that any one who wishes, up to the limited number, to go round with the guide and takes a ticket should be looked upon as a student and not have to pay anything. Clearly a person wishing to go round with a Guide Lecturer is a serious visitor, as proved by your providing him with instruction, and in every respect comes within the technical definition of a student. I hope that this may be considered at once, and until pay-days are abolished, there shall no longer be any payment of $6 \mathrm{~d}$. made on those who wish to go round with the Guide Lecturer.

The next institution I wish to refer to is Kew Gardens. Last year, according to the Return, no fewer than $3,800,000$ people went through the grounds. It is therefore a most popular resort. But according to the Return the number of people who went round with the Guide Lecturer numbered only 181 . The scheme 
there was consequently a complete failure. The Board of Agriculture admit it, and my noble friend Lord Lucas, I am sure, would be the first to agree that that is so. The failure arose from two reasons: first, that a prohibitive fee was imposed - a fee of half-a-crown in the morning and of a shilling in the afternoon-and the result was disastrous. The second reason was that no steps whatever, if I may be allowed to say so, were taken to make it known. There was no attempt at placards or advertisements. I am happy to say the authorities have now found out their mistake. Last November the fees were reduced to sixpence and threepence. A small fee in the forenoon must be imposed, because only a limited number can go round the plant huuses and the museums, and it is desirable that there should be a means like that of curtailing numbers. But although the fees have been reduced, the requisite steps have not been taken to make it known. I hope the Government will not mind my venturing to point this out, but the authorities have just issued a notice that if by September next the numbcrs are not greatly increased, the whole privilege will be withdrawn. That shows that they must be very anxious about the position, and cannot object to a few suggestions being offered.

I have taken some trouble in the matter, and I am convinced that if this scheme is put on a business footing at Kew Gardens, if something is done to encourage people to go there, the movement will be fully supported. In these days people are very fond of gardens and of flowers, and it would be an enormous satisfaction to the public to go round with the skilled andeminent botanist guide at Kew if they only knew they could do so. It is suggested, first of all, that the wretched system which has been adopted when people meetnamely, that they should meet at the portico of the Duke of Cambridge's old house on the Green-should be altered. I have gone there myself several times to see how it has worked. When you get there you find nobody to welcome you, and no large notice to show you have come to the right place. You find a bell which will not ring, a door which will not open, and no commissionaire or anybody there, and up to two or three minutes before the actual hour there is nothing to show you that you have not made a mistake, except, perhaps, a tiny little leaflet, and I know that many people who have gone there have gone away because they thought they had made a mistake. These are small matters, but they are important in regard to the failure or success of this experiment. As to placards, a large placard has now been put up outside the gates explaining the tours; but there is nothing inside the gates or any attempt to make them known to people who go in, and it is suggested that large placard posters similar to those outside the gates should be put up inside the gates, and at a few places in the grounds. I hope that these suggestions may receive attention. 'This is a most popular garden, and I know from the numerous letters I have received on the subject that an enormous number of people would be only too delighted to go round.

Next I wish to say a word with regard to the Tower of London. I know that my noble friend Lord Beauchamp, who is in charge of this institution, is keenly alive to the 
matter, and I am aware that there are many difficulties connected with the subject; the rooms are small, and the numbers who go there are very large. But if I might make a humble suggestion, it is this. The noble Earl is a trustee of the " London Museum," which has been so well arranged as regards its exhibits and labels. At every door as you go in you see described exactly what you are going to see, and it is put in large letters. People are not ashamed of it, as they seem to be in other places. If something of that sort could be done at the Tower until it is found possible to have a guide lecturer, it would be a very good thing. I hope that before long the Government may see their way to appoint a permanent committee of the directors of all the great museums and the authorities of the Board of Education to consider the various subjects connected with it as I am sure it would be found to be of the greatest advantage.

I now move for the two Returns of which I have given notice. The first Return would be similar in every respect to the one which we had last year, except perhaps with one or two slight alterations; but the second Return would be of the Provinces. There are, as your Lordships know, no fewer than from 150 to 200 local museums in the Provinces. They are all doing a vast amount of good educationally, and I think a great deal of information could be obtained. But the special reason why I ask your Lordships to agree to this second Return is that the British Association have lately appointed an important Committee to go into the whole subject of museums, not only in this country but in the Dominions, and they are very anxious that they should go equipped with complete knowledge of what is done in this country. They have asked me to move for this Return, which I am bound to say is perhaps rather an inquisitorial one, but it is one which would be of great use. I am aware that the Board of Education could hardly authorise such a Return unless it was made voluntary, and I think that if it were stated that this information should only be given by such museums as agreed to give it, there could be no possible harm. I know that a large number of museums throughout the country are only too anxious to show the good work they are doing and the great benefits which are derived from their exhibits. We have now seven institutions in this country with a guide lecturer and one or two in Scotland, and all do exceedingly good work. I am sure the most rev. Primate, who has done so much in the British Museum and also in the Natural History Museum in helping to start these guide lecturers, will agree that the result has been most satisfactory. You now witness as you go round keenness, joy, and happiness depicted on the faces of the people, and you no longer see in those museums visitors with an uninterested and listless expression. If this matter is consolidated, which it will be if these small matters are looked into by the authorities, it will be a great boon to the country. I beg to move.

Moved, That there be laid before the House a Return for the current year similar to the return on Museums lately issued, and also a second Return dealing with the Provincial Museums.-(LovdSudeley). 
LORD ZOUCHE OF HARYNGWORTH : My Lords, as I took a humble part in the debate on this subject last year, perhaps I may be allowed to say a few words this evening. I should like first to congratulate the noble Lord who has just sat down on the great success which has attended the movement which he brought forward originally with so much zeal. The way in which this scheme has been taken up and appreciated by the public is very satisfactory. Mention has been made as to the cost of these lecturers. Of course, nothing can be done without calculating the cost, although the expense here is not a serious amount. If this subject is considered on its merits and considered carefully, there is no reason why public money should be expended to an undue amount. There have been various suggestions made at different times as to how this cost should be defrayed. There was an article in The Times in October, 1911, in which it was said that probably the best results would be brought about by enlisting the services of specialists and amateurs, appointed or sanctioned by the learned societies and institutions, to deal at stated times with the sections with which they were familiar, and the system of paid guides might then be avoided. There may be many advantages in that suggestion and there may be objections to it, but it seems to me a suggestion of a practical nature, and I think the noble Lord who has just sat down said on one occasion that there was no particular reason in his opinion why small fees should not be charged in certain circumstances. For instance, supposing it is desirable that public tours limited to twenty-five should be free, why should not private parties be charged a shilling each person? I do not think the matter presents any special difficulties which cannot be got over with a little careful thought, and I heartily wish to commend the whole subject to your Lordships' consideration. I once had the privilege of going round with one of these lecturers at the Natural History Museum-it was quite a casual visit -and I was very much impressed with the way in which the guide gave his lecture on the subject of marine animals, I think it was. It seemed to me to be eminently practical, and it was followed with great attention by a fairly numerous number of people, although they were not too many to make an inconvenient crowd. I hope that His Majesty's Government will see their way to grant the Returns which have been moved for, and that the various difficulties which have been mentioned by the noble Lord will eventually be found capable of solution.

\section{ThE LORD ARCHBISHOP oF} CANTERBURY: My Lords, the noble Lord who has moved for these Returns appealed to myself as one who had had some experience in this matter. $\mathrm{He}$ is justified in doing so. It is true that from the outset of the endeavours in this direction which have been made in both branches of the British Museum-that in Bloomsbury and the Natural History Museum at Kensington - I have been personally deeply interested in the work done by the official guides, who have far exceeded any anticipation I had formed as regards the practical usefulness and effectiveness of the demonstrations which these guides are able to give to a body of 
persons who increasingly ask for their services. I am glad the thing was attempted at first on a small scale. It has grown in a natural and not in an artificial way. It will grow steadily, and before many years are passed we shall have, not two, but half a dozen guides in each of our museums taking different groups of persons round on different days. Nothing could have been more satisfactory than the way in which the work has been done. 'The testimony is quite universal as to the acceptableness and the popularity of the manner in which the expositions are given, and I am quite certain that we have found out at last a way of meeting what will, I hope and believe, be an increasing demand, and I think that every encouragement and all information available ought to be forthcoming so that we may set forward what I believe to be a good work which will certainly increase in the using.

\section{The Earl of PLYMOUTH :} My Lords, if I intervene for a moment between the House and the noble Earl who will reply, it is not that I claim any special knowledge of how the work of these official guides has been carried out. But I have taken pains to find out in connection with the National Gallery and the National Gallery of British Art (the Tate Gallery) what the opinion of the director is as to the success of this experiment, and I am informed that he has been more than satisfied, as the must rev. Primate has also testified, with the results in those two galleries. Twice daily in the mornings the lecturer goes round. Nearly always the lecture is fully attended, and I understand that it is most ably given. A number of other parties also arrange at other hours, by some few days' notice, to have the services of a lecturer, and I believe that in the Tate Gallery this privilege has been specially taken advantage of. I would add my small sum to the chorus of praise that has been given to my noble friend Lord Sudeley for the way in which he has been able to get these good results from the experiments that he has advocated. It is satisfactory to him and I trust that it is encouraging to $\mathrm{His}$ Majesty's Government to feel that the money expended has not been thrown away, and I am sure that the privilege would be more largely. used if the authorities could see their way to extend the number of these official guides.

\section{The FIRST COMMISSIONER} OF WORKS (Earl Beauchamp): My Lords, those of your Lordships who have taken the opportunity of perusing the Return which was moved for last year by the noble Lord opposite will, I am sure, agree that the interesting reading which it affords is more than a sufficient justification for the action of the noble Lord in having moved for it. His Majesty's Government will be glad to agree to the Motion for a similar Return in the present year, and with regard to the Provincial Museums we shall be pleased to communicate with the authorities concerned. The British Association for the Advancement of Science have advised that a Return for local museums should be issued, and we shall naturally take into consideration the weighty authority of that institution.

As to the abolition of pay-days at the Victoria and Albert Museum, I may say that at the present moment 
;ommunications are passing between the Board of Education and the Treasury on this subject, and that the Treasury are prepared to agree in principle to the abolition of the pay-days, but they feel some doubt $v$ hether it is practicable to make the inange at the present time in view of the increased facilities which might thereby be afforded for outrages such as those which have unhappily lately become common in our museums.

Then I come to the Imperial Institute. The noble Lord is no doubt aware that on March 10 the Secretary of State, in answer to a Question in another place, said that in view of other and more urgent demands upon the funds of the Imperial Institute he regretted that to had not so far felt justified in sanctioning the expenditure which gude demonstrators would necesitale, beyond the expense which the Institute already incurs in regard to ts present system of making known ot the pulslic the interesting nature of the collection which it contains. The estimates for this year have not so far been finally settled. There has been some delay owing to the absence of the director in Ceylon and India. When these estimates re considered the quescion of guide uemonstrators will not be forgotten, but, having regard to the organisa1 ' $n$ of a technical information spartment and the extra cost that will be thrown upon the funds of the 'nstitute, no promise can be given that it will be possible to find money this year for a guide demonstrator. I am sure the noble Lord will realise that the organisation of this technical information department will at any rate go some way towards making the public better acquainted with the contents of the Institute.

With regard to Kew Gardens I have been in communication with the Board of Agriculture on this matter, and from the information with which they have kindly furnished me it seems quite evident that the guide lecturer has not yet been fully appreciated by the public; and I think the noble Lord is right in ascribing this to the fact that the charges made to visitors for the services of the guide were originally much too high. They were reduced in November last, but, of course, the number of visitors to the gardens during the winter months is small, and it is hoped that during the present summer full advantage will be taken of the instruction offered. Notices have been issued to the Press, and there are also posters exhibited at the gates advertising the guide and the price for which his services may be secured. The Board of Agriculture will be very willing to consider carefully all possible means of popularising the tours. In conclusion, I have merely to repeat that we have no objection to the granting of the Returns for which the noble Lord has asked.

On Question, Mution agreed to, and order.d accordingly. 
The Times, Tuesday, May 5th, 1914.

\section{THE IMPERIAL INSTITUTE.}

\section{A Lack of Guide Demonstrators.}

To the Editor of the Times.

Sir,-Whilst matters of stupendous political importance are in the balance, it is found sometimes a pleasing relief to turn the attention to less important but urgent social matters.

May I venture, therefore, once more to ask your powerful aid in reference to an important matter in connexion with the appointment of guide-demonstrators to museums and galleries, for which you have so often pleaded?

Lord Beauchamp last week in the House of Lords, on behalf of the Government, stated (in a reply to questions that I put to him) how entirely successful the system had proved itself, and showed that no less than 84,000 people had been shown the various collections during the short time which had elapsed since guide-demonstrators had been appointed up to the 31st of last December.

$\mathrm{He}$ also stated that in the provinces there was a widespread interest in the subject, that the local authorities had taken up the matter warmly, and that demonstrations and facilities were continually being given in very many of the local museums.

With this otherwise exceedingly satisfactory account as to the progress of the system, I am forced to point out one serious blot, which requires early correction, in regard to the Imperial Institute.

In spite of repeated representations as to the desirability of the adoption of the system there, to which the authorities in the. Institute are believed to be favourable, there appears no sign of its initiation. In the House of Commons on March 10th the Colonial Secretary, in reply to a question, stated that the difficulty of expense stood in the way. When it is remembered that $£ 200$ is the paltry sum required as the salary for a guide-demonstrator to interpret and explain the products and $\overrightarrow{\mathrm{re}}$ sources of our great possessions beyond the seas, such a statement as to expense being the difficulty is trifling with the subject, and it is evident that the Colonial Office, with whom the matter rests, does not appreciate the enormous benefits which would attach to such an appointment.

It is inconceivable that the High Commissioners of the Dominions can remain quiescent and allow this great injustice to those they represent to remain without some steps being taken to alter the position. With the solitary exception of the Imperial Institute, founded specially to illustrate and explain Colonial products and resources, I believe every other museum and gallery in London connected with the Government have now obtained a grant from the Treasury to enable them to appoint a guide-demonstrator.

Surely it is nothing less than deplorable that the great collections of the Imperial Institute, with their vast educative potentialities and their tremendous possibilities of bringing the Mother Country into closer touch with the Dominions of the Empire, should, for the want of such a small outlay, be so little known to the majority of English men and women.

Your obedient servant, SUDELEY.

Ormeley Lodge, Han Common, Surrey, May 4. 
Microformed by Preservation Sorvices

min 6048.07 $5 / 96$ 





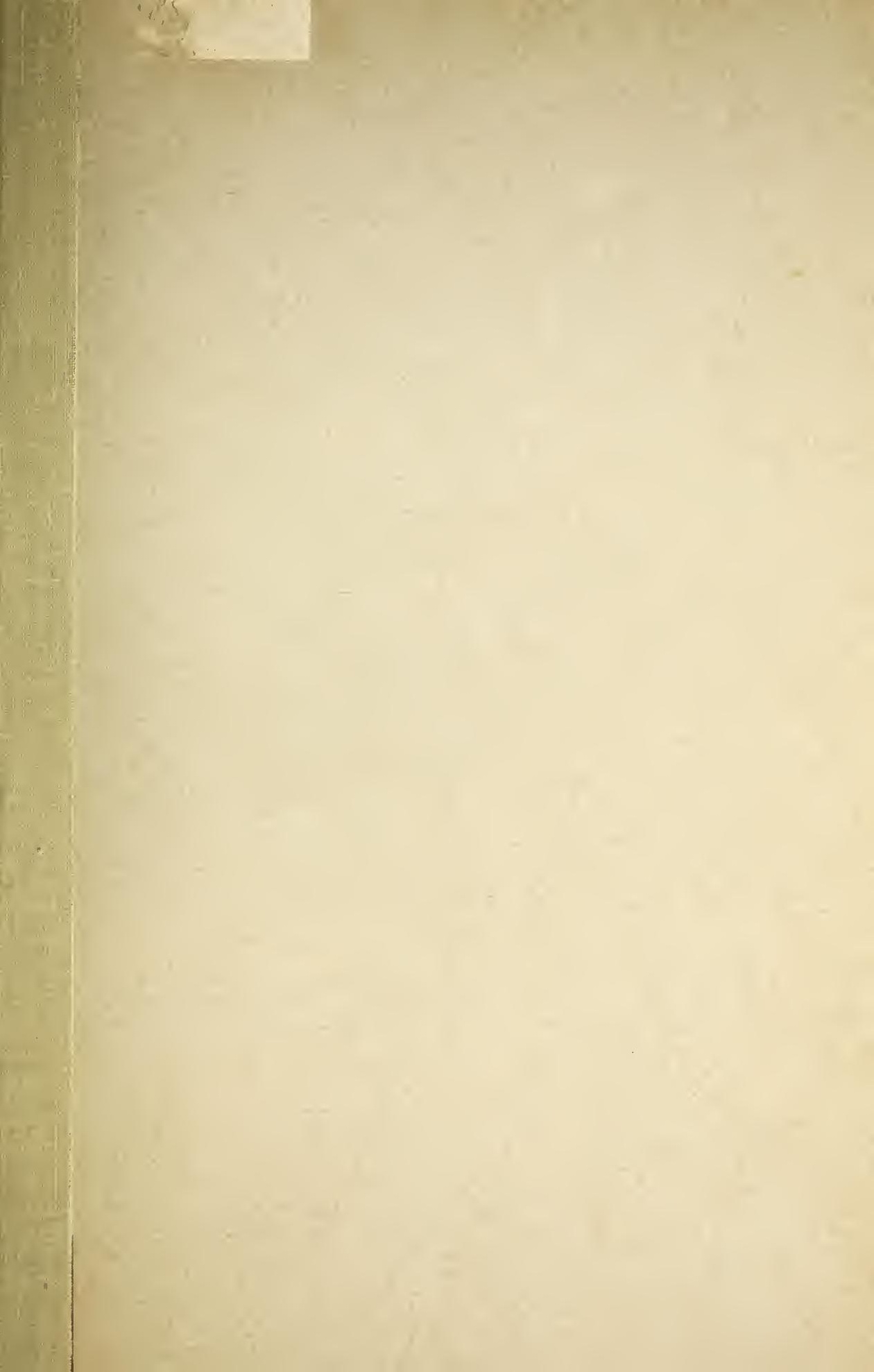


